\title{
AT-TARBAWI
}

At-Tarbawi: Jurnal Pendidikan, Sosial dan Kebudayaan

Volume 6 Nomor 1 Tahun 2019

doi: 10.32505/tarbawi.v6i1.997

\section{Implementasi Metode Saintifik oleh Guru PAI di SMA Se-Aceh}

\author{
Zainal Abidin Ishak ${ }^{1}$; Mohmad Noor Bin Mohmad Taib² \\ IAIN Langsa ${ }^{1}$ \\ Universiti Pendidikan Sultan Idris (UPSI) Malaysia² \\ zainalabidin.ishak75@gmail.com
}

\begin{abstract}
This study aims to determine the understanding of teachers of Islamic Education (PAI) about the scientific method in the implementation of the 2013 curriculum in designing and implementing PAI learning at the Aceh Province High School. The design of this study uses quantitative and qualitative approaches (mixed concurrent embedded / concurrent embedded strategy) implemented in 102 schools using questionnaire instruments and 12 schools using interview instruments. This study involved 211 PAI teachers who were selected through a purposive sampling, simple random sampling and cluster sampling for quantitative sampling and 12 respondents for qualitative. Analysis of quantitative research data using inference statistics through $t$-test analysis and using interview data analysis for qualitative. The results showed that there were significant differences in the ability of PAI teachers to understand the scientific method based on the substance of the 2013 curriculum. This shows that PAI teachers in the inner city better understand scientific learning methods compared to PAI teachers outside the City.
\end{abstract}

Keywords: Method, Scientific, Islamic Religious Education (PAI), High School, and Aceh

\begin{abstract}
Abstrak
Penelitian ini bertujuan untuk mengetahui pemahaman guru Pendidikan Agama Islam (PAI) tentang metode saintifik dalam implementasi kurikulum 2013 dalam merancang dan melaksanakan pembelajaran PAI pada Sekolah Menengah Atas (SMA) Provinsi Aceh. Desain penelitian ini menggunakan pendekatan kuantitatif dan kualitatif (mixed method concurrent nested/concurrent embedded strategy) yang dilaksanakan pada 102 sekolah dengan menggunakan instrumen kuesioner dan 12 sekolah menggunakan instrumen wawancara. Penelitian ini melibatkan 211 guru PAI yang dipilih melalui persampelan porposive sampling, simple random sampling dan cluster sampling persampelan untuk kuantitatif dan 12 responden untuk kualitatif. Analisis data penelitian kuantitatif menggunakan statistik inferensi melalui analisis uji-t serta menggunakan analisis data wawancara untuk kualitatif. Hasil penelitian menunjukkan terdapat perbedaan yang signifikan kemampuan guru PAI dalam memahami metode saintifik berdasarkan pada substansi kurikulum 2013. Ini menunjukkan bahwa guru PAI wilayah dalam Kota lebih memahami metode pembelajaran saintifik dibandingkan dengan guru PAI luar Kota.
\end{abstract}

Kata Kunci: Metode, Saintifik, Pendidikan Agama Islam (PAI), Sekolah Menengah Atas, dan Aceh. 


\section{A. Pendahuluan}

Perubahan dan pengembangan kurikulum 2013 di Indonesia merupakan bagian dari strategi meningkatkan pencapaian pendidikan yang berdasarkan pada kompetensi dan karakter siswa. Orientasi kurikulum 2013 adalah terjadinya peningkatan dan keseimbangan antara kompetensi sikap, keterampilan serta pengetahuan. Ini sejalan dengan isi Undang-Undang Pendidikan Nasional No. 20 Tahun 2003 pada pasal 35. Pasal 35 menyatakan bahwa Standar Kompetensi Lulusan (SKL) merupakan kelayakan lulusan yang meliputi aspek sikap, keterampilan dan pengetahuan yang sesuai dengan Standar Nasional Pendidikan yang telah ditetapkan.

Guru merupakan salah satu unsur penting dalam pelaksanaan kurikulum. Guru memiliki peranan dalam menentukan kesuksesan siswa, karena dengan kemampuan yang yang dimiliki guru akan menentukan keberhasilan siswa melalui pembelajaran yang dilaksanakan dalam kelas. Oleh karena itu, guru juga merupakan penentu kesuksesan pelaksanaan kurikulum, karena guru yang akan organisasikan pengalaman belajar siswa, sehingga dapat mengubah penampilan mereka secara bermakna atau tidak (Herry Sudjendro, 2014).

Menteri Pendidikan dan Kebudayaan R.I (Mendikbud), Muhammad Nuh memaparkan bahwa perubahan dan pengembangan kurikulum 2013 merupakan masalah yang penting yang harus senantiasa disesuaikan dengan perubahan zaman. Perlunya perubahan dan pengembangan kurikulum 2013 didasarkan pada beberapa hasil penelitian antar bangsa tentang kemampuan siswa Indonesia dalam kancah internasional. Perubahan dan pengembangan dimulai dengan observasi terhadap empat elemen standar nasional yaitu Standar Kompetensi Lulusan (SKL), Standar Isi (SI), Standar Proses (SP), dan Standar Penilaian (SPn) (Mulyasa, 2013).

Lody Paat (2012) dan H.A.R Tilaar (2012) mengatakan bahwa permasalahan utama dalam kurikulum 2013 adalah pelaksanaannya. Kurikulum 2013 dari segi konsep menawarkan sesuatu yang baru dan berbeda dari yang sebelumnya yaitu Kurikulum Tingkat Satuan Pendidikan (KTSP) 2006. "Tapi saya jamin pelaksanaannya tidak akan mulus karena 
persiapannya terutama untuk para guru tidak dibekali dengan pemahaman konsep yang matang," (Lody Paat, KOMPAS, 29 November 2012).

Hasil penelitian Mulyasa (2013) didapati banyak guru yang belum memahami kurikulum baru tersebut. Kabanyakan guru mengetahui perubahan kurikulum dari media cetak atau metia elektronik. Kekurangan penglibatan guru dalam menyebarkan kurikulum 2013 membuat berbagai pihak menganggap pelaksanaan kurikulum 2013 tidak akan berjalan lancar. Namun begitu, terdapat pihak yang mendukung perubahan kurikulum karena menganggap perubahan tersebut perlu untuk memenuhi tuntutan dan tantangan perkembangan zaman. Apabila tiada perubahan dalam kurikulum akan menyebabkan siswa tidak mempunyai kelayakan yang sesuai untuk diserapkan dalam dunia kerja (Kemendikbud, 2012).

Hasil anasilis publik menunjukkan bahwa sebahagian besar responden menyetujui pelaksanaan kurikulum 2013 dan sebanyak 71\% responden menunjukkan setuju terhadap justifikasi dan Standar Kompetensi Lulusan (SKL) kurikulum 2013. Selain itu sebanyak 81\% responden pula menyetujui mengenai persedian guru dalam pelaksanaan kurikulum 2013 (Kemendikbud, 2013). Oleh karena itu, untuk mensukseskan pelaksanaan kurikulum 2013, harus dimulai dengan peningkatan kualitas guru, yang masih mengahadapi banyak hambatan dan tentangan terutama dalam pelaksanaan pembelajaran. Kurikulum 2013 telah ditetapkan pelaksanaannya secara serentak pada tahun 2014 ini menjadi hal yang menakutkan bagi masyarakat serta menimbulkan keresahan dan kebingungan para guru.

Kegelisahan dan kebingungan ini dimulai dari training kurikulum 2013 yang tidak menyentuh keseluruhan sekolah sehingga hanya sebahagian guru saja yang menerima latihan tertentu. Selain itu, perubahan model pembelajaran dan penilaian yang dalam praktiknya kurang difahami oleh para guru. Banyak guru yang kebingungan karena tidak mampu menggunakan komputer, atau buta IT dan ada guru yang kuatir kehilangan sertifikasi guru karena kekurangan jam mengajar. Bahkan, banyak pula guru yang menolak atau tidak mau berdasarkan perubahan dan pengembangan 
kurikulum karena takut menghadapi sesuatu yang baru dan memberi dampak terhadap pekerjaannya bahkan takut meganggu kenyamanannya.

Berdasarkan keseluruhan persoal tersebut, peneliti melakukan penelitian dengan memfokuskan pada metode saintifik bagi guru PAI wilayah dalam Kota dan luar Kota dalam implementasi kurikulum 2013 pada mata pelajaran Pendidikan Agama Islam (PAI). Biasanya akan selalu mendapati tantangan ketika menghadapi sesuatu perubahan dan masalah-masalah baru yang menjadi kendala dalam pelaksanaan pembelajaran. Penelitian ini dilaksanakan se-Provinsi Aceh, objek penelitian ini dilakukan pada mata pelajaran Pendidikan Agama Islam (PAI) di Sekolah Menengah Atas (SMA).

Kesuksesan pelaksanaan kurikulum 2013 sangat tergantung pada pengetahuan dan pemahaman guru, karena guru sebagai perancang, pelaksana dan penilai pembelajaran. Guru harus memiliki pemahaman yang baik tentang tujuan, materi, metode dan penilaian pembelajaran yang sesuai dengan fakta, konsep dan teori-teori yang berlaku dalam kurikulum 2013. Berbagai panduan, seperti panduan guru maupun panduan siswa, yang sudah disiapkan oleh pemerintah, mulai dari pendekatan saintifik, proses yang pembelajaran kreatif sampai dengan penilaian otentik.

Hasil penelitian yang dilakukan oleh Nana Sudjana (2002) menunjukkan bahwa 76.6\%, hasil belajar siswa dipengaruhi oleh prestasi guru yaitu kemampuan guru mengajar sebanyak 32.43\%, penguasaan materi pelajaran sebanyak $32.38 \%$ dan sikap guru terhadap mata pelajaran sebanyak 8.60\%. Analisis kuantitatif Darling \& Hammon (2000) juga menunjukkan bahwa kualiti guru mempunyai korelasi yang kuat terhadap prestasi siswa. Hasil yang sama juga ditunjukkan oleh Schacter (2006) yang menyebutkan bahwa prestasi guru merupakan variabel penting dalam meningkatkan prestasi belajar siswa.

Hasil pengamatan Furqon (2014) menguraikan dedelapan permasalahan berkaitan dengan guru dalam pelaksanaan kurikulum 2013 yaitu, a) sukar mengubah mindset guru, b) perlu perubahan proses pembelajaran dari teacher centered ke student centered, c) moral spiritual yang rendah, d) budaya membaca dan mengkaji yang masih rendah, e) 
kurang penguasaan teknologi, f) lemah penguasaan bidang administrasi, g) kecenderungan guru yang lebih banyak menekankan aspek kognitif dan h) masih banyak guru yang belum mau menjadi pembelajar.

Beberapa penyelidik seperti Brophy \& Good (1986), Gurney (2007), Rosenshine \& Steven (1986), Reynolds \& Teddlie (2000) menyatakan tingkah laku guru memainkan peranan dalam pencapaian hasil belajar siswa. Antara faktor yang mempengaruhi pembelajaran yang berkesan telah diketahui oleh Bophy dan Good (1986) yaitu penstrukturan materi pembelajaran, menggunakan pengatur awal dan menyusun tujuan dan materi pembelajaran berdasarkan urutan serta kejelasan penjabaran atau penyampaian. Berdasarkan uraian tersebut jelas menunjukkan guru memiliki peranan penting sebagai pelaksana dan penentu kesuksesan kurikulum, karena tanpa pemahaman guru yang komprehensif tentang kurikulum akan menyebabkan pembelajaran dan pencapaian objektif kurikulum akan mengalami kesukaran dan kegagalan.

Kerangka konseptual penelitian ini dibagikan menjadi dua variabel yaitu variabel bebas dan terikat, dan tiga bagian yaitu demografi guru PAI, perubahan, pengembangan kurikulum 2013 dan elemen kurikulum PAI serta 12 konstruk seperti yang ditunjukkan dalam gambar 1. Namun demikian, dalam penelitian ini hanya membahas satu saja dari variabel bebas yaitu lokasi tempat kerja (wilayah dalam dan luar Kota).

\section{B. Metode}

Untuk melaksanakan penelitian ini, peneliti menggunakan desain gabungan kuantitatif dan kualitatif (mixed method concurrent nested/concurrent embedded strategy) (Creswell \& Clark, 2007). Penggunaan kedua metode ini dapat memantapkan temuan dan pemahaman tentang sesuatu fenomena yang terjadi diantara keduanya. Brewer dan Hunter (2005); Frechtling dan Shrap (1977) dan Sabitha (2006). Johnson, Onwuegbuzie dan Turner (2007) menekankan pendekatan metode gabungan membolehkan penelitian dilakukan dengan lebih mendalam dan meluas untuk meningkatkan pemahaman dan dukungan data. Penggunaan teknik 
wawancara bukan saja mendukung dan menambahkan bukti tetapi juga membantu mengesahkan hasil yang diperoleh dari kuesioner (Cohen, Manion \& Morrison, 2000). Neuman (2006) dan Woods (2006) berpendapat penggunaan beberapa metode akan menjelajahi dan meningkatkan peluang peneliti untuk mengkaji secara mendalam dan lebih tepat.

Populasi adalah guru Pendidikan Agama Islam (PAI) wilayah dalam Kota dan luar Kota yang telah mengikuti pelatihan kurikulum 2013. Teknik persampelan adalah persampelan bertujuan (purposive sampling), persampelan rawak (simple random sampling) dan persampelan kluster (cluster sampling). Penetapan ukuran sampel dalam penelitian ini adalah sebanyak 211 orang sampel berdasarkan tabel Krejcie dan Morgan.

Instrumen penelitian ini untuk mendapatkan data kuantitatif adalah kuesioner dalam bentuk Skala Likert dan soal Objektif. Ini merupakan instrumen yang dibentuk secara khusus untuk mengumpulkan data dalam rangka menjawab persoal penelitian (Mohd Majid, 2000; Sabitha, 2006). Manakala Metode interview digunakan untuk memperoleh data kualitatif. interview berstruktur melibatkan penjadwalan yang ketat, yaitu peneliti akan tanyakan setiap responden penelitian soal yang sama dengan gaya atau cara yang sama dan telah tersedia pedoman wawancara tentang apa yang hendak diteliti, (Ghaziah, Nabilah, Shireena, Rohaya \& Norshidah 2010).

\section{Hasil dan Pembahasan}

Isi Kurikulum Tingkat Satuan Pendidikan (KTSP) 2006 atau Kurikulum 2006 secara keseluruhan telah banyak mengalami perubahan dan pengembangan daripada kurikulum baru iaitu Kurikulum 2013. Lazimnya setiap perubahan dan pengembangan kurikulum akan selalu berhadapan dengan tantangan dan perkara-perkara baru yang berlaku sebagai halangan, hambatan atau tantangan dalam pelaksanaan pembelajaran di dalam kelas.

Hasil analisis data kuantitatif menunjukkan bahwa uji-t berdasarkan Skala Likert untuk konstruk Perubahan dan Pengembangan kurikulum 2013 yang memuat 8 sub konstruk dan Elemen Kurikulum yang memuat 4 sub kontruk secara keseluruhan didapati signifikan. Ini menunjukkan bahwa 
terdapat perbedan yang signifikan antara guru PAI wilayah dalam Kota dan luar Kota dalam memahami dan melaksanakan kurikulum 2013 berkaitan dengan metode saintifik sesuai dengan konsep kurikulum 2013. Guru PAI wilayah dalam Kota lebih memahami perencanaan dan pelaksanaan pembelajaran dengan metode saintifik dibandingkan dengan guru PAI wilyah luar Kota.

Manakala uji-t berdasarkan soal Objektif untuk konstruk Perubahan dan Pengembangan kurukulum 2013 yang memuat 8 sub konstruk dan Elemen Kurikulum yang memuat 4 sub kontruk hanya 2 sub kontruk saja yang signifikan dan mendukung hasil temuan Skala Likert yaitu sub konstruk Standar Metode (SMet) dan Standar Rencana Pelaksanaan Pembelajaran (RPP). Ini bermaksud bahwa ada perbedaan yang signifikan diantara guru PAI dalam memahami substansi yang berkaitan dengan metua sub kontruk di atas. Berikut ini adalah hasil kuantitatif secara rinci sesuai dengan masingmasing hipotesis.

Pemahaman guru PAI terhadap konstruk perubahan dan pengembangan Kurikulum 2013 meliputi delapan (8) sub konstruk. Hasil analisis deskriptif berdasarkan jenis kelamin berada pada tahap yang tinggi. Ini bermakna bahwa guru PAI lelaki maupun guru perempuan memiliki pemahaman yang baik tentang perubahan dan pengembangan Kurikulum 2013 serta mampu mengimplementasikannya dalam kegiatan pembelajaran di dalam kelas.

Hasil itu menunjukkan bahwa guru PAI memiliki pemahaman terhadap elemen kurikulum PAI yang meliputi objektif, isi, metode dan penilaian pembelajaran. Dengan demikian, secara amnya guru PAI baik laki-laki maupun perempuan juga memiliki pemahaman yang baik terhadap konstruk perubahan dan pengembangan Kurikulum 2013, serta juga memiliki pemahaman terhadap elemen kurikulum PAI yang meliputi sub kontruk masing-masing, secara konseptual dan juga dalam pelaksanaannya.

Pemahaman guru PAI yang tinggi ini turut telah didukung berdasarkan hasil wawancara dengan guru PAI dalam kota secara semua guru PAI secara amnya boleh memahami aspek-aspek yang berubah daripada kurikulum KTSP 
2006 kepada Kurikulum 2103, misalnya perkara-perara yang berkaitan dengan objektif, metode dan penilian dalam kurikulum 2013. Antara pendapat yang dikemukakan oleh guru adalah seperti berikut:

“...Dalam diskusi bisa menilai sikap dan keahlian. Misalnya mempresentasikan, itukan sudah ada nilai keahlian, dalam diskusi kita lihat disiplin, tanggung jawabnya, bertanya, santunnya menggunakan kata-kata yang baik, itukan sudah ada penilaian. Kalau kognitif kita bisa memberikan ujian lisan, atau ujian tulisan, dan soal uraian". (Kod: NSD /DB/TB1/KF/No. B. 253-269)

“...Tahapan-tahapan yang dalam pembelajaran kurikulum 2013, itu sangat menonjol dan sangat mendasar sekali ya itu dibidang saintifiknya. Dimana disitu kalau dulu itu awal-awal pembelajaran ada 5 langkah-langkah kurikulum 2013. Mengacu dengan langkah-langkah tersebut, yang pertama itu langkah mengamati, jadi mengamati apakah nanti disitu, seorang guru itu menyediakan dalam bentuk video atau film dan sebagainya itu". Lalu kesimpulan tersebut nanti mereka akan menyampaikan pada tahapan terakhir yang disebutkan dengan mengkomunikasikan". (Kod: SFL /DB/TB2/KF/No. B.126-154)

Berdasarkan hasil wawancara di atas menunjukkan bahwa guru PAI memiliki pemahaman yang tinggi tentang perubahan dan pengembangan kurikulum 2013. Demikian juga guru PAI boleh memahami sisi perubahan objektif PAI, isi pembelajaran PAI, metode pembelajaran PAI demikian juga penilaian pembelajaran PAI. Hal ini mendukung hasil kuantititatif dengan skala Likert yang mendapati pemahaman guru PAI pada tahap yang tinggi.

Hasil analisis deskriptif soal Objektif tentang pemahaman guru PAI bagi konstruk perubahan dan pengembangan Kurikulum 2013 yang meliputi delapan sub konstruk menunjukkan berada pada tahap tinggi (SPen, KDar, RPP) dan tahap sederhana (SKL, SKand, Sked, StrKur, SukPem) yang menyatakan keseluruhan berada pada tahap tinggi. Sejalan dengan hasil di atas, seterusnya analisis deskriptif soal objektif bagi konstruk elemen kurikulum PAI yang meliputi empat sub konstruk juga berada pada tahap tinggi (KanPAI) dan tahap sederhana (ObPAI, KenPAI, PenPAI) berkaitan pemahaman guru PAI terhadap Kurikulum 2013. Perbedaan hasil soal Likert dan soal objektif di atas dapat memberi informasi berbeza, ini menunjukkan pemahaman dan kesungguhan guru PAI dalam memahami instrumen kajian. 
Hal ini dapat dilihat pada rumusan dan implikasi kajian yang bisa dijadikan sebagai satu bentuk arah tuju dalam membuat sebarang keputusan untuk meningkatkan pemahaman guru berkaitan dengan sesuatu pengetahuan yang baru. Namun demikian, hasil di atas telah menunjukkan bahwa hasil analisis deskriptif saling memberikan dukungan untuk mempekokoh hasil kajian ini.

Hasil kuantitatif dengan soal Objektif tentang pemahaman guru PAI yang tinggi ini turut didukung berdasarkan hasil wawancara yang dilakukan dalam kota. Antara pendapat yang dikemukakan oleh guru adalah seperti berikut:

"... KI (kompetensi inti) satu mengenai spritual, ketuhanan dia, jadi pada saat dia belajar pokoknya kita ramu kita padukan semua antara KI satu sampai KI empat ada disitu KI satu sikap religiusnya, sikap dia terhadap ke Tuhanannya harus diwujudkan dalam materi yang dipelajari, serta KI dua sikap sosial dia yaitu sikap sosial dia dengan kawan-kawannya bagaimana dia membimbing dirinya dengan kawannya punya sikap sosial peduli terhadap kawan sesama, terus KI tiga pengetahuan kita lihat pelajar itu ketika dia belajar tentang materi yang kita ajari, kita lihat pengetahuan dia sejauhmana baik itu sebelum kita mengajar ataupun nanti setelah kita mengajar. Terus KI yang terakhir keahlian". (Kod: FZH /DB/TB5/KF/No. B. 54-71)

“...Ya kalau RPP (Rencana Pelaksanaan Pembelajaran) saya buat sendiri dengan mengacu pada langkah-langkah kurikulum 201. Yang pertama sekali identitas sekolah, kemudian KI itu, di bawah KI itu ada Kompetensi Dasar, kemudian indikator, sesudah indikator tujuan pembelajaran, kemudian materi, kemudian disanan langkah-langkah pembelajaran mulai dari kegiatan awal, kegiatan inti dan kegiatan akhir, terus disana setelah langkah-langkah itu ada penilaian, media, sumber belajar dan sebagainya". (Kod: SYN /DB/TB6/KF/No. B. 94-114)

Manakala hasil wawancara yang laksanakan pada 12 SMA yaitu sekolah Wilayah dalam dan luar Kota terdiri dari dua belas responden mendukung hasil dari analisis data kuantitatif. Hal ini menunjukkan bahwa terdapat perbedaan dalam memahami dan melaksanakan metode saintifik dalam pembelajaran PAI dikalangan guru PAI berdasarkan wilayah dalam dan luar Kota. Secara keseluruhan responden guru PAI dalam wilayah dalam Kota lebih memahami metode saintifik sesuai konsep kurikulum 2013 berbanding dengan guru PAI luar Kota. Hasil wawancara menunjukkan terdapat 
perbedaan antara responden di dalam kota dan luar kota dari segi kuantitas iaitu jumlah pelatihan yang diikuti maupun kualitas yaitu pelaksanaan pelatihan di dalam kota lebih berkualitas berbanding pelatihan yang dilaksanakan kepada guru di luar kota. Hal ini terjadi karena pelaksanaan pelatihan di dalam kota banyak dihadiri oleh pembimbing/tutor nasional dan juga guru PAI di dalam kota mempunyai banyak peluang berdasarkan pelatihan Kurikulum 2013 di ibu kota seperti di Jakarta dan sekitarnya.

Oleh itu, bahan-bahan yang diperolehi daripada pembimbing peringkat nasional lebih berkualiti berbanding dari wilayah yang diperolehi daripada pembimbing peringkat wilayah seperti yang dialami oleh guru PAI di luar kota. Demikian juga, fungsi pengurusan pengetuan sekolah di dalam kota lebih kreatif jika dibandingkan dengan pengetua sekolah di luar kota. Hal ini dapat dilihat melalui cara memberdayakan guru dalam melaksanakan tugasan mereka dan juga cara penilaian hasil kinerja guru serta pola musawarah, dan penyelesaian masalah yang dihadapi oleh guru dan lain-lain.

Guru di dalam kota mendapati kerjasama yang baik dengan pengetua sekolah, melalui musawarah pengetua sekolah dalam kota juga selalu memberikan pengetahuan-pengetahuan yang berkaitan dengan pelaksanaan pembelajaran mengikut Kurikulum 2013. Demikian juga pengetua sekolah mengupayakan sendiri untuk mengawasi pembelajaran dalam kelas pada setiap guru dan memberikan catatan-catatan dalam yang ia temukan dalam kelas kepada guru untuk meningkatkan pembelajaran apabila ditemukan halhal yang masih perlu penambahbaikan. Manakala guru di luar kota secara amnya tidak mendapati hal sama dengan guru di dalam kota, ini dikarenakan fasiliti sekolah di dalam dan di luar kota memiliki perbedaan yang kentara.

\section{Kesimpulan}

Penelitian ini telah memberi gambaran berkenaan metode saintifik dalam pembelajaran PAI terhadap implementasi kurikulum 2013 dalam merancang dan melaksanakan pembelajaran PAI pada Sekolah Menengah Atas (SMA) wilayah dalam Kota dan luar Kota se-Provinsi Aceh. Hasil

penelitian secara umumnya didapati bahwa guru PAI pada SMA wilayah 
dalam Kota memiliki pemahaman terhadap metode saintifik sesuai dengan substansi kurikulum 20013 yang merangkumi konstruk perubahan dan pengembangan kurikulum, demikian juga dengan konstruk elemen kurikulum PAI.

Dengan demikian, untuk meningkatkan pemahaman guru PAI tentang metode saintifik dalam pembelajaran PAI perlu dilakukan pelatihan, komunikasi/ musyawarah antar guru, kerjasama kepala sekolah dengan instansi lain, penyedian sarana prasarana, kesadaran guru untuk melakukan perubahan diri dan evaluasi kegiatan pembelajaran. Beberapa dari hasil penelitian ini bisa dijadikan sebagai informasi untuk merancang panduan atau modul untuk pelaksaanaan kurikulum 2013 berkaitan wilayah dalam dan luar Kota yang perlu diberikan perhatian yang berbeda dan maksimal.

Berdasarkan lokasi tempat kerja ujian-t soal skala Likert dan soal Objektif bagi konstruk perubahan dan pembangunan Kurikulum 2013 dan elemen kurikulum PAI secara keseluruhan adalah signifikan. Ini bermakana bahawa terdapat perbedaan pemahaman antara guru PAI di dalam kota dan guru PAI di luar kota berkaitan dengan perubahan dan pembangunan Kurikulum 2013. Guru PAI di dalam kota memiliki pemahaman yang lebih baik berbanding dengan guru PAI di luar kota. Dapatan ini menunjukkan bahawa guru di dalam kota lebih menguasai objektif, kandungan, kaedah dan penilaian dalam pembelajaran PAI di dalam bilik kota.

Hasil wawancara menunjukkan terdapat perbedaan pemahaman antara responden di dalam dan luar kota. pemahaman guru PAI dalam dan luar kota dipengaruhi oleh banyak hal di antaranya adalah jumlah pelatihan yang diikuti oleh guru PAI di dalam kota lebih banyak dari segi jumlah dan lebih baik segi kualitas, pelaksanaan pelatihan di dalam kota lebih berkualiti berbanding pelatihan yang dilaksanakan bagi guru di luar kota. Hal ini karena pelaksanaan pelatihan di dalam kota ramai dihadiri oleh pembimbing atau pakar peringkat nasional dan juga guru PAI di dalam kota dapat mengikuti banyak pelatihan Kurikulum 2013 yang diselenggarakan di ibu kota dan sekitarnya. 


\section{DAFTAR PUSTAKA}

Abd. Ghafar Md. Din. 2003. Prinsip dan amalan pengajaran. Kuala Lumpur : Utusan Publication dan Distributors Sdn. Bhd.

Ahmad, Muhammad Abdul Qadir. 2008. Metologi pengajaran agama Islam. Jakarta: PT. Rineka Cipta.

Aqib Zainal, dan Elham. 2008. Membangun Profesionalisme Guru Dan Pengawas Sekolah, Bandung: CV Yrama Widya.

Arifin, H.M. 2003. Ilmu Pendidikan Islam: Tinjauan Teoritis dan Praktis Berdasarkan Pend ekatan Interdisipliner, ed.Rev, Jakarta: Bumi Aksara.

Arikunto, Suharsimi. 1998. Prosedur Penelitian; suatu pendekatan dan praktek. Cet ke-11. Jakarta: PT. Rineka Cipta.

Babbie, E. 2001. The practice of social research. Edisi ke 9. Belmont, CA: Wadsworth.

Bady, L \& Kennedy, L. 1999. Curriculum Construction. Sydney: Prentice Hall.

Ball, S.J. 1985. School Politics, Teachers' Careers and Educational Change: A case study of becoming a compre- hensive school. In L. Barton and S. Walker (eds), Education and Social Change. London: Croom Helm.

Behar, L.S. 1994. The knowledge base of curriculum: an empirical analysis. (Lanham, MD: University Press of America).

Bloom, B.S. (Ed). 1979. Taxonomy of Educational Objectives. London: Longman Group Ltd.

Chua, Y.P. 2006. Metode dan statistik penyelidikan. Metode penyelidikan. Buku 1. Kuala Lumpur: McGraw-Hill Education.

Chua, Y.P. 2006. Metode dan statistik penyelidikan. Metode penyelidikan. Buku 2. Kuala Lumpur: McGraw-Hill Education.

Chuan, Y.P. 2006. Research Methods. Shah Alam: McGraw-Hill Education.

Cohen, L. \& Manion, L. 2000. Research method in education. Edited by 5. London: Routlege Falmer.

Cohen, L. \& Manion, L. 1994. Research methods in education. Ed. Ke-4. London: Kogan Page. 
Creswell, J.W. 2005. Educational research: planing, conducting and evaluating, quantitative and qualitative research. Ed. Ke-2 Upper Saddle River, NJ: Pearson.

Davis, D. 2002. Business research for decision making. Ed. Ke-5. New York: Duxbury Thomson Learning, University of Central Florida.

Drake, Susan M. 2013. Menciptakan terintegrasi yang berbasis standar. Ed. Ke3. Jakarta: PT. Indeks.

Fraenkel, J. R., \& Wallen, N.E,. 1996. How to design an evaluate research in education 3rd edition. Newyork: McGraw-Hill.

Fullan, M. 1993. Change forces: probing the depths of education reform. London: Falmer Press.

Fullan, M. 2007. The New Meaning of educational change, New York: NY., Teacher Collage press.

Fullan, M.G. \& Stiegelbauer, S. 1991. The new meaning of educational change (2nd edition). New York Teachers College Press.

Fullan, M.G. 1982. The meaning of educational change. New York: Teachers College Colombia University.

Gagne, R.M. 1975. Essentials of Learning for Instruction. New York: Holt. Rinchart and Winston.

Gay, L.R., Mills, G.E., \& Airasian, P. (Eds.). 2006. Education Research. Competencies for Analysis and Applications (8 th ed). Upper Saddle River: Pearson Educational, Inc.

Gunawan, Heri. 2013. Kurikulum dan pembelajaran pendidikan Agama Islam. Cet ke-2 Bandung: CV. Alfabeta.

Gutek, L. Gerald L. 2004. Philosophical and ideological voices in education. Pearson Education.

Hair, J.F., W.C., Babin, B.J., Anderson, R.E., \& Tatham, R.L. 1998. Multivariate data analysis. New Jersey: Pearson Education International.

Hamalik, Oemar. 2009. Dasar-dasar pengembangan kurikulum. Cet ke-3. Bandung: PT. Remaja Rosdakarya.

Hamalik, Oemar. 2013. Kurikulum dan pembelajaran . Cet ke-13. Jakarta: Bumi Aksara. 
Hamdan, Abdul Rahim. 2007. Pengajian kurikulum. Cet. Ke-3. Johor Bahru, Johor Darul ta'zim : UTM Press.

Hammond L.D. and Hudson, L., 1990 Precollege Sdciense and Mathematica Teachers: Supply, Demand and Quality. In Marianne Amarel, at.al., (Ed) Review of Researc In Education 1989-1990. Washington: DC.: AERA.

Hamzah, Mohd. Daud. 1994. Desainkurikulum sekolah. Selangor Darul Ehsan: Percetakan Dewan Bahasa dan Pustaka Lot1037, Mukim Perindustrian PKNS.

Haryati, Mimin. 2008. Model Teknik Penilaian Pada Tingkat Satuan Pendidikan, Jakarta: Gaung Persada Press.

Hasan, Hamid. 2009. Evaluasi kurikulum, cet. Ke-2. Bandung: PT. Remaja Rosdakarya.

Hidayat, Ara., \& Imam Machali. 2012. Konsep, prinsip, dan aplikasi dalam mengelola sekolah dan madrasah. Yogyakarta: Kaukaba.

Hidayat, Sholeh. 2013. Pengembangan kurikulum baru. cet. Ke-2. Bandung: PT. Remaja Rosdakarya.

Hosnan, M. 2014. Pendekatan saintifik dan kontekstual dalam pembelajaran abad 21; kunci sukses implementasi kurikulum 2013. Cet Ke-2. Bogor: Ghalia Indonesia.

Idi, Abdullah. 2014. Pengembangan kurikulum; teori \& praktik. Jakarta: RajaGrafindo Persada.

Idris, Noraini. 2010. Penyeledikan dalam pendidikan. Malaysia: McGraw Hill. Sdn.Bhn.

Ismail, Ramlee, at all. 2014. Analisis data kuantitatif. Kuala Lumpur: Kaisar Metia Kreatif.

Jalaluddin, \& Abdullah Idi. 2010. Filsafat pendidikan; manusia, filsafat, dan pendidikan. Cet ke-3. Yogyakarta: Ar-Ruzz Metia.

Kamus Dewan edisi ke empat. 2005. Selangor: Dewan Bahasa dan Pustaka.

Kamus Dewan edisi ke empat. 2007. Selangor: Dewan Bahasa dan Pustaka.

Kemendiknas. 2010. Pengembangan KTSP SMA, Jakarta: Direktorat Pembinaan SMA. 
Khairuddin, Junaedi, Mahfud, dkk. 2007. Kurikulum Tingkat Satuan Pendidikan, Konsep dan Implementasinyadi Madrasah, Yogyakarta: Nuansa Aksara.

Krejcie R. V., \& Morgan D.W. 1970. Determining sample size for research activities. Educational and Psychological Measurement. 30,607-610. 
